\title{
Gas exchange of citrus rootstocks in response to intensity and duration of saline stress
}

\section{Trocas gasosas de porta-enxertos de citros em resposta a intensidade e duração do estresse salino}

\author{
Roberta Chaiene Almeida Barbosa ${ }^{1 *}$; Marcos Eric Barbosa Brito ${ }^{2}$; \\ Francisco Vanies da Silva Sá3 ; Walter dos Santos Soares Filho \\ Pedro Dantas Fernandes ${ }^{5}$; Luderlândio de Andrade Silva ${ }^{3}$
}

\begin{abstract}
Soil and water salinity cause physiological disorders in sensitive plants, such as altered gas exchange in citrus genotypes. However, it is possible to analyse these effects and to identify genotypes tolerant to salt stress. An experiment was carried out in order to evaluate the tolerance of citrus genotypes considering the irrigation with saline water during rootstock formation. The study took place under greenhouse conditions in Pombal county, Paraiba, Brazil. A randomised block design was used, with treatments arranged in a factorial scheme $(5 \times 8)$. The two factors were: [i] five salinity levels of irrigation water $\left(0.8,1.6,2.4,3.2\right.$ and $\left.4.0 \mathrm{dS} \mathrm{m}^{-1}\right)$ and [ii] eight genotypes of citrus rootstocks: 1. 'Santa Cruz Rangupur' lime (LCRSTC); 2. common 'Sunki' mandarin (TSKC) x 'Swingle' citrumelo (CTSW) - 028; 3. TSKC x CTSW - 033; 4. TSKC x CTSW - 041; 5. 'Volkamer' lemon (LVK) x 'Rangpur' lime (LCR) - 038; 6. 'Florida Sunki' mandarin (TSKFL); 7. TSKC and 8. 'Florida' rough lemon (LRF). Gas exchange was evaluated at 15,30 and 60 days after the beginning of the saline water application. High water salinity reduces gas exchange in citrus genotypes, which was more evident at 15 days from the beginning of stress. The genotypes 'Santa Cruz Rangpur' lime, TSKC x CTSW - 041, LVK x LCR 038 and 'Florida' rough lemon exhibit a satisfactory physiological behaviour during the first 30 days of exposure to the stress, showing moderate tolerance to salt stress. The genotypes TSKC x CTSW - 033 and common 'Sunki' mandarin are the most sensitive to salinity.
\end{abstract}

Key words: Citrus spp. Poncirus hybrids. Salinity. Assimilation rate. Tolerance.

\section{Resumo}

A salinidade do solo e da água ocasionam distúrbios fisiológicos em plantas sensíveis, a exemplo das trocas gasosas em genótipos de citros, podendo-se identificar, a partir dessas variáveis, genótipos tolerantes e a resposta das plantas à salinidade. Assim, objetivou-se avaliar a tolerância de genótipos de citros à salinidade na fase de formação de porta-enxertos. O experimento foi desenvolvido em casa de vegetação, no Município de Pombal, Paraíba, empregando-se o delineamento experimental de blocos casualizados com três repetições e tratamentos arranjados em esquema fatorial, $5 \times 8$, relativos à

\footnotetext{
1 Técnica de Laboratório, Universidade Federal de Campina Grande, UFCG, Centro de Ciências e Tecnologia Agroalimentar, CCTA, Pombal, PB, Brasil. E-mail: robertachaiene@ccta.ufcg.edu.br

2 Prof., Dr., UFCG, CCTA, Pombal, PB, Brasil, Bolsista PQ do CNPq. E-mail: marcoseric@pq.cnpq.br

3 Discentes, Curso de Doutorado do Programa de Pós-Graduação em Engenharia Agrícola, UFCG, Centro de Tecnologia e Recursos Naturais, CTRN, Campina Grande, PB, Brasil. E-mail: vanies_agronomia@hotmail.com; luderlandioandrade@gmail.com

${ }^{4}$ Pesquisador A, Empresa Brasileira de Pesquisa Agropecuária, EMBRAPA Mandioca e Fruticultura, Cruz das Almas, BA, Brasil, Bolsista PQ do CNPq, E-mail: walter.soares@embrapa.br

${ }^{5}$ Prof. Dr., UFCG, CTRN, Campina Grande, PB, Brasil, Bolsista PQ do CNPq. E-mail: pdantas@pq.cnpq.br

* Author for correspondence
} 
combinação de: [i] cinco níveis de salinidade da água de irrigação $\left(0,8 ; 1,6 ; 2,4 ; 3,2\right.$ e 4,0 dS m m$\left.^{-1}\right)$ e [ii] oito genótipos de porta-enxertos de citros: 1. limoeiro 'Cravo Santa Cruz' (LCRSTC); 2. tangerineira 'Sunki' comum (TSKC) x citrumelo 'Swingle' (CTSW) - 028; 3. TSKC x CTSW - 033; 4. TSKC x CTSW - 041; 5. limoeiro 'Volkameriano' (LVK) x limoeiro 'Cravo' (LCR) - 038; 6. tangerineira 'Sunki da Flórida' (TSKFL); 7. TSKC e 8. limoeiro 'Rugoso da Flórida' (LRF). Avaliaram-se as trocas gasosas das plantas aos 15, 30 e 60 dias após o início da aplicação de água salina. A salinidade da água reduziu as trocas gasosas de genótipos de citros, sendo mais evidente aos 15 dias após o início do estresse. Os genótipos limoeiro 'Cravo Santa Cruz', TSKC x CTSW - 041, LVK x LCR - 038 e o limoeiro Rugoso da Flórida têm comportamento fisiológico satisfatório durante os primeiros 30 dias de exposição ao estresse, sendo moderadamente tolerantes ao estresse salino. Os genótipos TSKC x CTSW - 033 e a tangerineira Sunki Comum são mais sensíveis à salinidade.

Palavras-chave: Citrus spp. Híbridos de Poncirus. Salinidade. Fotossíntese líquida. Tolerância.

\section{Introduction}

Brazil is the third largest fruit producer in the world (FAO, 2014). It therefore goes without saying that the fruit-growing sector is of utmost social, dietary and economic importance for the country. Among the fruit crops, citrus fruits stand out as the most important produce, especially sweet orange [Citrus sinensis (L.) Osbeck], which is the most produced and exported crop. Citrus production in the country is distributed throughout all regions, but the main producing region is the southeast, which accounts for $79 \%$ of the national production. In contrast, the northeast contributes $10 \%$ to the total national production, with a mean yield of $13.8 \mathrm{tha}^{-1}$, which is much lower than the national mean of 23.8 t ha-1 (IBGE, 2016).

The low yields obtained in Northeast Brazil can be attributed to the sparing use of technologies that optimize the production, for instance the selection of rootstocks with higher tolerance to biotic and abiotic stresses. Another factor might be the prevalent water deficit in the hottest months of the year, which points to the necessity of using irrigation systems in order to achieve yield increases, as observed by Braz et al. (2009), who studied the impacts of irrigation frequency and depths on Tahiti lime $[C$. latifolia (Yu Tanaka) Tanaka] production.

However, although irrigation can reduce the climatic risk of drought and losses of citrus orchards in the Northeastern region, it must be highlighted that the water used for irrigation, which is usually obtained from wells, has relatively high salt concentrations, which can influence the growth, development and yield of the salt-sensitive citrus plants (MAAS, 1993; MEDEIROS et al., 2003; LEVY; SYVERTSEN, 2004; DIAS et al., 2012).

The effect of high salinity levels on citrus is attributed to the toxicity of chlorine, sodium and boron ions as well as to increased osmotic stress (LEVY; SYVERTSEN, 2004; DIAS; BLANCO, 2010). Dias and Blanco (2010) report that the tolerance to salinity comprehends successive biochemical reactions regulated by specific genes. According to some authors (FERNANDES et al., 2011; BRITO et al., 2014; HUSSAIN et al., 2015), this tolerance is variable among species and, within the same species, among the different stages of plant development and age. Those authors also highlight that in citrus plants, the tolerance to salinity can be associated with the accumulation of toxic ions in the vacuole or with the exclusion of these ions in the roots, being variable especially in the rootstock. Such capacity of adaptation is very useful and allows the selection of salt-tolerant genotypes when it is not possible to maintain low levels of soil and water salinity (TESTER; DAVENPORT, 2003; SYVERTSEN; GARCIA-SANCHEZ, 2014).

Thus, it is necessary to diversify plant materials, notably citrus rootstocks, to obtain materials with higher efficiencies in growth and physiological aspects under conditions of abiotic stresses, such as those caused by high salinity. In this context, Silva et al. (2014) and Brito et al. (2016) could identify salt stress in citrus genotypes, based on gas exchange 
and chlorophyll fluorescence, and classified some genotypes with respect to their sensitivity to stress, using these variables in hydroponic conditions, with evaluation in the initial stage of stress application. Hence, based on physiological variables and under a condition of higher stress in time and concentration, it is possible to increase the number of genotypes and identify their tolerance levels.

Thus, this study aimed to evaluate the salinity tolerance of varieties and hybrids of citrus rootstocks in the initial growth stage through evaluating gas exchange in different periods from the beginning of the stress application.

\section{Materials and Methods}

The experiment was carried out in a protected environment at the Centre of Sciences and Agri-Food Technology, CCTA, of the Federal University of Campina Grande, UFCG, located in the municipality of Pombal, Paraíba, Brazil. The geographic coordinates are $6^{\circ} 47^{\prime} 20^{\prime \prime} \mathrm{S}$ and $37^{\circ} 48^{\prime} 01^{\prime \prime} \mathrm{W}$, at an altitude of $194 \mathrm{~m}$.

The experimental design consisted of randomised blocks, with a factorial scheme composed of two factors:

Five levels of irrigation water salinity $\left(\mathrm{EC}_{\mathrm{w}}\right): \mathrm{S}_{1}$ $=0.8 ; \mathrm{S}_{2}=1.6 ; \mathrm{S}_{3}=2.4 ; \mathrm{S}_{4}=3.2$ and $\mathrm{S}_{5}=4.0 \mathrm{dS} \mathrm{m}^{-1}$, with one level being below and four levels above the water salinity that guarantees a relative yield of $100 \%\left(1.1 \mathrm{dS} \mathrm{m}^{-1}\right)$ for orange fruits, described in Ayers and Westcot (1999). It should be pointed out that water with these $\mathrm{EC}_{\mathrm{w}}$ values is common in the northeastern region (MEDEIROS et al., 2003).

Eight genotypes of citrus rootstocks, recommended as rootstocks by the Program of Genetic Breeding of Citrus of the Embrapa Cassava and Fruits: 1. 'Santa Cruz Rangpur' lime ( $C$. limonia Osbeck) (LCRSTC); 2. common 'Sunki' mandarin [C. sunki (Hayata) hort. ex Tanaka] (TSKC) x 'Swingle' citrumelo [C. paradisi Macfad. x Poncirus trifoliata (L.) Raf.] (CTSW) - 028; 3. TSKC x CTSW - 033; 4. TSKC x CTSW - 041; 5. 'Volkamer' lemon (C. volkameriana V. Ten. \& Pasq.) (LVK) x 'Rangpur' lime (LCR) - 038; 6. 'Florida Sunki' mandarin (TSKFL); 7. common 'Sunki' mandarin (TSKC); 8. 'Florida' rough lemon (C. jambhiri Lush.) (LRF).

The combination of factors results in 40 treatments (5 salinity levels $\mathrm{x} 8$ rootstocks), repeated in 3 blocks, in which each plot consisted of 8 evaluated plants, totalling 120 plots.

Irrigation water was prepared in such a way to obtain a proportion equivalent to $7 \mathrm{Na}: 2 \mathrm{Ca}: 1 \mathrm{Mg}$, using $\mathrm{NaCl}, \mathrm{CaCl}_{2} \cdot 2 \mathrm{H}_{2} \mathrm{O}$ and $\mathrm{MgCl}_{2} \cdot 6 \mathrm{H}_{2} \mathrm{O}$.

Prior to sowing, the seeds were selected and treated with the fungicide thiram disulphide (4 g $\mathrm{kg}^{-1}$ of seeds). In each $115 \mathrm{~mL}$ tube, we planted two seeds and filled the tube with commercial substrate containing a combination of vermiculite, pine bark and humus at the proportion of 1:1:1. The chemical composition of the substrate used in the experiment is presented in Table 1 and was determined according to the methodology recommended by EMBRAPA (2009).

Table 1. Substrate chemical characteristics.

\begin{tabular}{|c|c|c|c|c|c|c|c|c|c|c|c|c|}
\hline $\begin{array}{c}\mathrm{pH} \\
\left(\mathrm{H}_{2} \mathrm{O}\right)\end{array}$ & E.C. & $\mathrm{P}$ & $\mathrm{K}$ & $\mathrm{Na}$ & $\mathrm{Ca}$ & $\mathrm{Mg}$ & $\mathrm{Al}$ & $\mathrm{H}+\mathrm{Al}$ & SB & $(\mathrm{T})$ & $\mathrm{NaRS}$ & MO \\
\hline & $\mathrm{dS} \mathrm{m}^{-1}$ & $\mathrm{mg} \mathrm{dm}^{-3}$ & ----- & - & $\mathrm{cmol}$ & $\mathrm{lm}^{-3}-$ & - & & $\mathrm{cmol}_{\mathrm{c}}$ & $\mathrm{Im}^{-3}$ & $\%$ & $\mathrm{mg} \mathrm{dm}^{-3}$ \\
\hline 6.4 & 0.6 & 3.0 & 0.5 & 0.3 & 9.2 & 7.5 & 0.0 & 1.2 & 17.2 & 17.2 & 1.8 & 52.0 \\
\hline
\end{tabular}


After the emergence stage, 60 days after sowing (DAS), only one seedling (ungrafted) was kept in each container. Abnormal seedlings, in relation to the standard of each genotype, were eliminated to discard eventual individuals of sexual origin, as we wanted to maintain only those of apogamic origin (nuclear), according to Carvalho et al. (2005). Thus, given the time required for this selection, the treatments started at $60 \mathrm{DAS}$ and the experiment ended at 120 DAS, i.e., 60 days after salt stress application (DASSA).

Irrigation was performed manually using a cylinder mm-graduated cylinder; the volume applied per tube $\left(\mathrm{V}_{\mathrm{a}}\right)$ was determined through drainage lysimetry at each salinity level, added of a leaching fraction (LF) of $20 \%$. Containers were used to collect the volume drained from the tubes of each plot and $\mathrm{V}_{\mathrm{a}}$ was obtained by the difference between the total volume applied during the night $\left(\mathrm{V}_{\mathrm{ta}}\right)$ and the volume drained $\left(\mathrm{V}_{\mathrm{d}}\right)$ in the morning of the next day in each plot, dividing the result by the number of containers (n) and applying the LF, as indicated in Equation 1:

$$
V a=\frac{V_{t a}-V_{d}}{n(1-L F)}
$$

The salinity of the drained water was monitored weekly for each salinity level through quantification of the electrical conductivity of the drainage water $\left(\mathrm{EC}_{\mathrm{dw}}\right)$, using a portable conductivity meter (Instrutherm ${ }^{\circledR}$ ) with conductivity automatically corrected to $25^{\circ} \mathrm{C}$.

We used the $\mathrm{EC}_{\mathrm{dw}}$ data to calculate the estimate of the electrical conductivity of the saturation extract ( $\mathrm{EC}_{\mathrm{e}}$ ) (Figure 1), using Equation 2 (AYERS; WESTCOT, 1999):

$$
E C_{e}=\frac{E C_{d w}}{2}
$$

Figure 1. Estimative of electrical conductivity of the extract of saturated soil paste $\left(\mathrm{EC}_{\mathrm{e}}\right)$ during experimental period for water salinity levels, $0.8,1.6,2.4,3.2$ and $4.0 \mathrm{dS} \mathrm{m}^{-1}$.

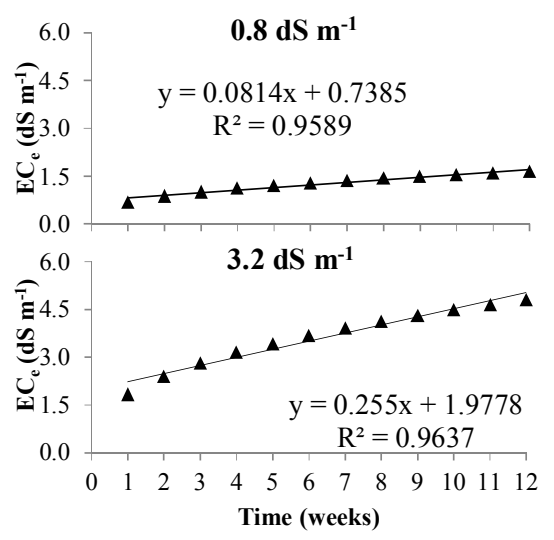

We performed all recommended measures of pest prevention and control in citrus seedlings (QUAGGIO et al., 2005).

Plant gas exchange was determined using an infrared gas analyser (IRGA - LCpro+) with constant light of $1,200 \mu \mathrm{mol}$ of photons $\mathrm{m}^{-2} \mathrm{~s}^{-1}$,

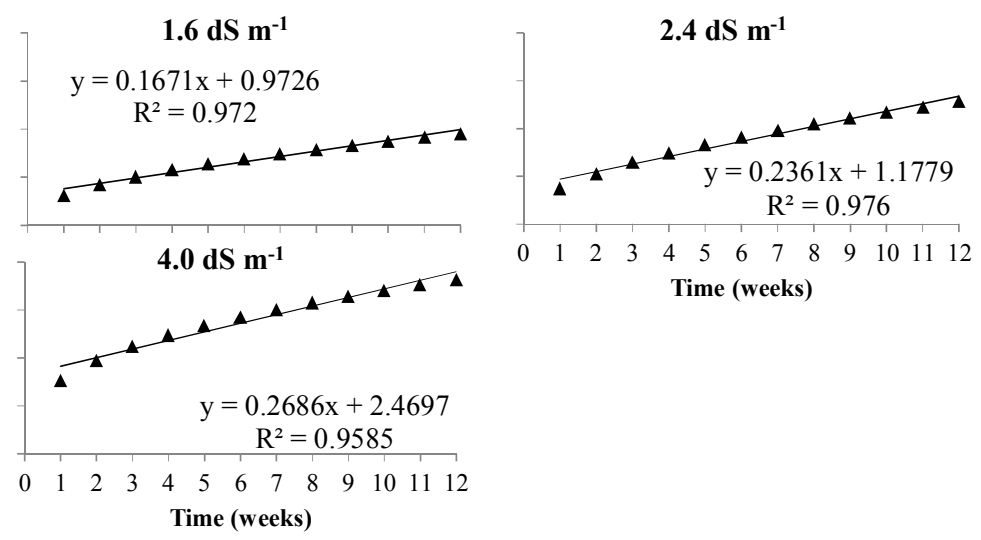

obtaining the following variables: $\mathrm{CO}_{2}$ assimilation rate $(A)$, expressed in $\mu \mathrm{mol}\left(\mathrm{CO}_{2}\right) \mathrm{m}^{-2} \mathrm{~s}^{-1}$; internal $\mathrm{CO}_{2}$ concentration $\left(C_{i}\right)$, in $\mu \mathrm{mol}\left(\mathrm{CO}_{2}\right) \mathrm{mol}^{-1}$; transpiration $(E)$, in mmol $\left(\mathrm{H}_{2} \mathrm{O}\right) \mathrm{m}^{-2} \mathrm{~s}^{-1}$; stomatal conductance $(g s)$, in $\mathrm{mol}\left(\mathrm{H}_{2} \mathrm{O}\right) \mathrm{m}^{-2} \mathrm{~s}^{-1}$. These data were used to quantify intrinsic water use efficiency 
(IWUE) by the ratio between $A$ and $E$, (IWUE = $A / E)$, expressed in $\left[\mu \mathrm{mol}\left(\mathrm{CO}_{2}\right) \mathrm{m}^{-2} \mathrm{~s}^{-1}\right][\mathrm{mmol}$ $\left.\left(\mathrm{H}_{2} \mathrm{O}\right) \mathrm{m}^{-2} \mathrm{~s}^{-1}\right]^{-1}$, and the instantaneous carboxylation efficiency $\left(E I C_{i}\right)$ dividing $A$ by $C_{i}\left(E I C_{i}=A / C_{i}\right)$, expressed in $\left[\left(\mathrm{mmol}\left(\mathrm{CO}_{2}\right) \mathrm{m}^{-2} \mathrm{~s}^{-1}\right)(\mu \mathrm{mol} \mathrm{mol})^{-1}\right)^{-}$ 1] (MACHADO et al., 2005; BRITO et al., 2012). These data were obtained at 15, 30 and 60 days after salt stress application (DASSA), on the first mature leaf counted from the apex, with evaluations between 7 and 9 a.m.

The obtained data were subjected to analysis of variance by $\mathrm{F}$ test. In case of significance, polynomial regression analysis (linear and quadratic) was applied for the factor irrigation water salinity, and the means grouping test (Scott-Knott until 0.05 probability level) was applied for the factor rootstock (FERREIRA, 2011).

\section{Results and Discussion}

There were significant differences between the genotypes $(\mathrm{p}<0.01)$ for the variables internal $\mathrm{CO}_{2}$ concentration $\left(C_{i}\right)$, stomatal conductance $(g s)$, transpiration $(E)$, photosynthesis $(A)$, intrinsic water use efficiency (IWUE) and instantaneous carboxylation efficiency $\left(E I C_{i}\right)$ in all evaluation periods (Table 2).

The source of irrigation water salinity variation significantly influenced all variables, except $C_{i}$ and IWUE, at 15 and 30 DASSA (Table 2). Thus, the stress was established shortly after the beginning of the salinity treatments, extending up to 30 DASSA in a more accentuated way, since there was no significant effect of salinity on the variables at 60 DASSA, except for $E$ (Table 2).

Table 2. Summary of analysis of variance for internal $\mathrm{CO}_{2}$ concentration $(\mathrm{Ci}) \mu \mathrm{mol}\left(\mathrm{CO}_{2}\right) \mathrm{mol}^{-1}$, stomatal conductance $(g s)\left(\mathrm{mol}\left(\mathrm{H}_{2} \mathrm{O}\right) \mathrm{m}^{-2} \mathrm{~s}^{-1}\right)$, transpiration $(E)\left(\mathrm{mmol}\left(\mathrm{H}_{2} \mathrm{O}\right) \mathrm{m}^{-2} \mathrm{~s}^{-1}\right)$, assimilation rate $(A)\left(\mu \mathrm{mol} \mathrm{m}^{-2} \mathrm{~s}^{-1}\right)$, instantaneous water use efficiency $(I W U E)\left[\left(\mu \mathrm{molCO}_{2} \mathrm{~m}^{-2} \mathrm{~s}^{-1}\right)\left(\mathrm{mmolH}_{2} \mathrm{O} \mathrm{m}^{-2} \mathrm{~s}^{-1}\right)^{-1}\right]$ and instantaneous carboxylation efficiency $\left(E I C_{i}\right)$ $\left[\left(\mathrm{mmol}\left(\mathrm{CO}_{2}\right) \mathrm{m}^{-2} \mathrm{~s}^{-1}\right)\left(\mu \mathrm{mol} \mathrm{mol}^{-1}\right)^{-1}\right]$, to 15,30 and 60 days after salt stress application (DASSA) on citrus genotypes under different levels of salt stress from irrigation water.

\begin{tabular}{|c|c|c|c|c|c|c|c|c|}
\hline \multicolumn{9}{|c|}{ Mean square } \\
\hline Variable & $\begin{array}{c}\text { Time } \\
\text { (DASSA) }\end{array}$ & $\begin{array}{l}\text { Genotype } \\
\text { (G) }\end{array}$ & $\begin{array}{r}\text { Salt } \\
(\mathrm{S})\end{array}$ & $\mathrm{G} \times \mathrm{S}$ & Block & Error & Mean & $\begin{array}{l}\text { CV } \\
(\%)\end{array}$ \\
\hline \multirow{3}{*}{$C_{i}$} & 15 & $1391.58^{* *}$ & $691.66^{* *}$ & $511.48^{* *}$ & $246.27^{\mathrm{ns}}$ & 127.04 & 257.96 & 4.37 \\
\hline & 30 & $1170.86^{* *}$ & $669.40^{\mathrm{ns}}$ & $948.51^{* *}$ & $3017.07^{* *}$ & 357.07 & 255.24 & 7.40 \\
\hline & 60 & $1524.49^{* *}$ & $125.69^{\mathrm{ns}}$ & $734.15^{* *}$ & $714.26^{\mathrm{ns}}$ & 359.78 & 248.96 & 7.62 \\
\hline \multirow{3}{*}{ gs } & 15 & $0.0138^{* *}$ & $0.0084^{* *}$ & $0.0019^{* *}$ & $0.0040^{* *}$ & 0.0007 & 0.113 & 23.37 \\
\hline & 30 & $0.0058^{* *}$ & $0.0036^{*}$ & $0.0008^{\mathrm{ns}}$ & $0.0044^{*}$ & 0.001 & 0.102 & 31.42 \\
\hline & 60 & $0.0072^{* *}$ & $0.0010^{\text {ns }}$ & $0.0007^{\mathrm{ns}}$ & $0.0014^{\mathrm{ns}}$ & 0.0005 & 0.07 & 31.5 \\
\hline \multirow{3}{*}{$E$} & 15 & $2.2467^{* *}$ & $2.1912^{* *}$ & $0.3849^{* *}$ & $2.3945^{* *}$ & 0.1712 & 2.158 & 19.17 \\
\hline & 30 & $0.9960^{* *}$ & $0.9630^{* *}$ & $0.1932^{\mathrm{ns}}$ & $0.8953^{*}$ & 0.2103 & 2.147 & 21.36 \\
\hline & 60 & $1.1522^{* *}$ & $0.2797^{*}$ & $0.1911^{*}$ & $0.0616^{\mathrm{ns}}$ & 0.1062 & 1.422 & 22.93 \\
\hline \multirow{3}{*}{$A$} & 15 & $24.289^{* *}$ & $11.958^{* *}$ & $4.1843^{* *}$ & $0.4170^{\mathrm{ns}}$ & 0.9855 & 5.639 & 17.60 \\
\hline & 30 & $30.298^{* *}$ & $11.712^{* *}$ & $2.2608^{\mathrm{ns}}$ & $2.9935^{\mathrm{ns}}$ & 1.4510 & 5.425 & 22.21 \\
\hline & 60 & $19.848^{* *}$ & $3.8035^{\mathrm{ns}}$ & $2.0998^{\mathrm{ns}}$ & $3.2449^{\mathrm{ns}}$ & 1.5613 & 4.422 & 28.25 \\
\hline \multirow{3}{*}{ IWUE } & 15 & $0.4233^{* *}$ & $0.1298^{\mathrm{ns}}$ & $0.3613^{* *}$ & $3.5247^{* *}$ & 0.1047 & 2.645 & 12.23 \\
\hline & 30 & $3.6397^{* *}$ & $0.6597^{*}$ & $0.2713^{\mathrm{ns}}$ & $2.8168^{* *}$ & 0.2436 & 2.532 & 19.49 \\
\hline & 60 & $1.4076^{* *}$ & $0.2545^{\mathrm{ns}}$ & $0.4998^{* *}$ & $1.3241^{* *}$ & 0.1533 & 3.094 & 12.65 \\
\hline \multirow{3}{*}{$E I C_{i}$} & 15 & $0.00042^{* *}$ & $0.00016^{* *}$ & $0.00008^{* *}$ & $0.00001^{\mathrm{ns}}$ & 0.00002 & 0.022 & 19.00 \\
\hline & 30 & $0.00056^{* *}$ & $0.00023^{* *}$ & $0.00006^{* *}$ & $0.000007^{\mathrm{ns}}$ & 0.00003 & 0.022 & 23.46 \\
\hline & 60 & $0.00032^{* *}$ & $0.00006^{\mathrm{ns}}$ & $0.00005^{\mathrm{ns}}$ & $0.00003^{\mathrm{ns}}$ & 0.00003 & 0.018 & 30.56 \\
\hline \multicolumn{2}{|c|}{ DF } & 7 & 4 & 28 & 2 & 78 & - & - \\
\hline
\end{tabular}

$\mathrm{DF}=$ degrees of freedom; $\mathrm{CV}=$ coefficient of variation; $* *, *$ and $\mathrm{ns}=$ significance to $1 \%, 5 \%$ and non-significant by $\mathrm{F}$-test, respectively 
The interaction $\mathrm{G} \times \mathrm{S}$ (Table 2) had different effects on each variable. For $C_{i}$, there was a significant effect of $\mathrm{G} \times \mathrm{S}(\mathrm{p}<0.01)$ in all periods; for $g s$, the interaction was significant only at 15 DASSA; in relation to $E$, interaction occurred at 75 $(\mathrm{p}<0.01)$ and 120 DAS $(\mathrm{p}<0.05)$; for $A$, there was a statistically significant difference at 15 DASSA ( $<<0.01$ ); for the variables $I W U E$ and $E I C_{i}$, the interaction was not significant at 30 and 60 DASSA, respectively. These differences may be related to the fact that the citrus rootstocks differed regarding their capacities to exclude toxic ions, especially chlorine and sodium, consequently leading to different salinity tolerances (AYERS; WESCOT, 1999).
The increase in salinity drastically reduced the $\mathrm{CO}_{2}$ assimilation rate of the genotypes TSKC $\mathrm{x}$ CTSW -033 and TSKC, causing decreases of 58.3 and $46.6 \%$ when photosynthesis was compared to the salinity levels of 0.8 and $4.0 \mathrm{dS} \mathrm{m}^{-1}$, respectively, at 15 days after the onset of stress application (Table 3). This behaviour reflects the high salinity sensitivity of these genotypes, because, at the same salinity level, net photosynthesis decreased in the readings at 30 and 60 days, in comparison to the values obtained at 15 days after the beginning of the stress (Table 3).

Table 3. Assimilation rate $(A)\left(\mu \mathrm{mol}\left(\mathrm{CO}_{2}\right) \mathrm{m}^{-2} \mathrm{~s}^{-1}\right)$ to 15,30 and 60 days after salt stress application (DASSA) on citrus genotypes under different levels of salt stress from irrigation water.

\begin{tabular}{|c|c|c|c|c|c|}
\hline \multicolumn{6}{|c|}{ Assimilation rate $(A)$} \\
\hline \multicolumn{6}{|c|}{15 DASSA } \\
\hline \multirow{2}{*}{ Genotype } & \multicolumn{5}{|c|}{ Salt stress from irrigation water $\left(\mathrm{dS} \mathrm{m}^{-1}\right)$} \\
\hline & 0.8 & 1.6 & 2.4 & 3.2 & 4 \\
\hline LCRSTC & $7.41 \mathrm{~A}$ & $8.52 \mathrm{~A}$ & $6.04 \mathrm{~A}$ & $5.70 \mathrm{~A}$ & $5.61 \mathrm{~A}$ \\
\hline TSKC x CTSW -028 & $3.84 \mathrm{~B}$ & $3.69 \mathrm{~B}$ & $4.61 \mathrm{~A}$ & $4.06 \mathrm{~B}$ & $4.41 \mathrm{~A}$ \\
\hline TSKC x CTSW -033 & $8.04 \mathrm{~A}$ & $5.87 \mathrm{~A}$ & $4.51 \mathrm{~A}$ & $3.27 \mathrm{~A}$ & $3.36 \mathrm{~A}$ \\
\hline TSKC x CTSW -041 & $5.35 \mathrm{~B}$ & $5.06 \mathrm{AB}$ & $4.62 \mathrm{AB}$ & $4.62 \mathrm{~A}$ & $3.83 \mathrm{~A}$ \\
\hline LVK x LCR - 038 & $7.73 \mathrm{~A}$ & $8.48 \mathrm{~A}$ & $9.10 \mathrm{~A}$ & $5.13 \mathrm{~A}$ & $5.14 \mathrm{~A}$ \\
\hline TSKFL & $4.07 \mathrm{~A}$ & $5.23 \mathrm{~A}$ & $4.66 \mathrm{~A}$ & $5.88 \mathrm{~A}$ & $5.41 \mathrm{~A}$ \\
\hline TSKC & $5.29 \mathrm{~A}$ & $6.52 \mathrm{~A}$ & $5.57 \mathrm{~A}$ & $4.34 \mathrm{~A}$ & $2.83 \mathrm{~A}$ \\
\hline \multirow[t]{2}{*}{ LRF } & $6.56 \mathrm{AB}$ & $7.23 \mathrm{AB}$ & $8.76 \mathrm{~A}$ & $9.09 \mathrm{~A}$ & $6.12 \mathrm{~A}$ \\
\hline & \multicolumn{5}{|c|}{30 DASSA } \\
\hline \multirow{2}{*}{ Genotype } & \multicolumn{5}{|c|}{ Salt stress from irrigation water $\left(\mathrm{dS} \mathrm{m}^{-1}\right)$} \\
\hline & 0.8 & 1.6 & 2.4 & 3.2 & 4 \\
\hline LCRSTC & $6.70 \mathrm{~A}$ & $7.68 \mathrm{AB}$ & $6.90 \mathrm{~A}$ & $5.84 \mathrm{~A}$ & $5.75 \mathrm{~A}$ \\
\hline TSKC x CTSW -028 & 4.91 AB & $6.26 \mathrm{~A}$ & $6.33 \mathrm{~A}$ & $7.18 \mathrm{~A}$ & $4.83 \mathrm{~A}$ \\
\hline TSKC x CTSW -033 & $5.14 \mathrm{~B}$ & $4.25 \mathrm{AB}$ & $4.39 \mathrm{~A}$ & $3.93 \mathrm{~A}$ & $2.94 \mathrm{~A}$ \\
\hline TSKC x CTSW -041 & $7.73 \mathrm{~A}$ & $6.80 \mathrm{~A}$ & $5.95 \mathrm{~A}$ & $4.48 \mathrm{~A}$ & $5.37 \mathrm{~A}$ \\
\hline LVK x LCR - 038 & $6.46 \mathrm{~A}$ & $8.07 \mathrm{~A}$ & $6.91 \mathrm{AB}$ & $7.20 \mathrm{AB}$ & $6.23 \mathrm{~A}$ \\
\hline TSKFL & $3.35 \mathrm{~A}$ & $3.98 \mathrm{~A}$ & $5.50 \mathrm{~A}$ & $3.56 \mathrm{~B}$ & $2.64 \mathrm{~B}$ \\
\hline TSKC & $2.78 \mathrm{~B}$ & $3.65 \mathrm{~B}$ & $4.37 \mathrm{~A}$ & $3.26 \mathrm{~A}$ & $2.84 \mathrm{~A}$ \\
\hline LRF & $8.34 \mathrm{~A}$ & $8.43 \mathrm{~A}$ & $6.22 \mathrm{~B}$ & $5.53 \mathrm{~B}$ & $4.31 \mathrm{~A}$ \\
\hline \multicolumn{6}{|c|}{60 DASSA } \\
\hline \multirow{2}{*}{ Genotype } & \multicolumn{5}{|c|}{ Salt stress from irrigation water $\left(\mathrm{dS} \mathrm{m}^{-1}\right)$} \\
\hline & 0.8 & 1.6 & 2.4 & 3.2 & 4 \\
\hline LCRSTC & $3.80 \mathrm{~B}$ & $5.69 \mathrm{~B}$ & $6.40 \mathrm{~A}$ & $6.43 \mathrm{~A}$ & $6.51 \mathrm{~A}$ \\
\hline TSKC x CTSW -028 & $6.20 \mathrm{~A}$ & $5.42 \mathrm{AB}$ & $5.84 \mathrm{~A}$ & $3.23 \mathrm{~B}$ & $3.85 \mathrm{~A}$ \\
\hline TSKC x CTSW -033 & $4.17 \mathrm{~B}$ & $2.83 \mathrm{~B}$ & $3.37 \mathrm{~A}$ & $2.48 \mathrm{~A}$ & $2.55 \mathrm{~A}$ \\
\hline TSKC x CTSW -041 & $2.29 \mathrm{C}$ & $3.71 \mathrm{~B}$ & $3.63 \mathrm{~B}$ & $3.72 \mathrm{~A}$ & $3.70 \mathrm{~A}$ \\
\hline LVK x LCR - 038 & $6.61 \mathrm{~A}$ & $7.35 \mathrm{~A}$ & $6.77 \mathrm{~B}$ & $4.95 \mathrm{~B}$ & $4.73 \mathrm{~A}$ \\
\hline TSKFL & $4.08 \mathrm{~A}$ & $3.54 \mathrm{~A}$ & $3.69 \mathrm{~A}$ & $3.65 \mathrm{~B}$ & $3.00 \mathrm{~B}$ \\
\hline TSKC & $3.04 \mathrm{~B}$ & $4.12 \mathrm{~B}$ & $4.12 \mathrm{~A}$ & $3.03 \mathrm{~A}$ & $3.70 \mathrm{~A}$ \\
\hline LRF & $4.51 \mathrm{~B}$ & $5.20 \mathrm{~B}$ & $5.62 \mathrm{~B}$ & $5.41 \mathrm{~B}$ & $3.98 \mathrm{~A}$ \\
\hline
\end{tabular}

*LCRSTC: 'Santa Cruz Rangupur' lime (Citrus limonia Osbeck); TSKC: common 'Sunki' mandarin [C. sunki (Hayata) hort. ex Tanaka]; CTSW: 'Swingle' citrumelo [C. paradisi Macfad. x Poncirus trifoliata (L.) Raf.]; LVK: 'Volkamer' lemon (C. volkameriana V. Ten. \& Pasq.); LCR: 'Rangpur' lime; TSKFL: 'Florida Sunki' mandarin; LRF: 'Florida rough lemon (C. jambhiri Lush.). Means followed by different letters indicate the difference between rootstocks by Tukey test at 0.05 probability level. 
Additionally, in the genotype TSKC x CTSW - 028, there was no reduction and in LRF, the reduction was on average $6 \%$ between the lowest and highest levels of irrigation water salinity at 15 DASSA, which means that these two genotypes have a higher physiological potential in comparison to the others. Furthermore, in the evaluation performed 15 days after the beginning of saline water application, we observed the greatest differentiation between treatments, suggesting that, as salt stress becomes continuous, the plant develops tolerance mechanisms (SILVA et al., 2014). Multiple stress may have occurred along with salt stress, as indicated by Syvertsen and Garcia-Sanchez (2014), e.g., restricted root growth in the narrow tubes. Therefore, we recommend that the plants are only kept in such containers up to 90 days after sowing, i.e., 30 DASSA.

Even at 30 DASSA, photosynthetic activity of the genotype LRF was restricted when irrigation water with an EC level of at least $2.4 \mathrm{dS} \mathrm{m}^{-1}$ was used. Such restriction caused by salinity can be related to the osmotic effect resulting from salinity, limiting water availability and, consequently, gas exchange, particularly in photosynthesis, as observed in other studies (DIAS et al., 2012; BRITO et al., 2012). In addition, ionic effects might have played a role, since plants had been under irrigation with saline water for 30 days in a relatively small volume of substrate; this corroborates with the findings of Hussain et al. (2015), who related low photosynthesis values in citrus leaves to a low detoxification capacity, leading to the accumulation of ions in the cell vacuole. This is common in lemons, because they are less tolerant to salinity; this has also been observed by Rebequi et al. (2009), who reported growth reduction in 'Rangpur' lime plants in the rootstock stage under salt stress.

It must be highlighted that the estimated $\mathrm{EC}_{\mathrm{e}}$ (Figure 1) exceeded the threshold salinity in the soil for citrus plants, $1.4 \mathrm{dS} \mathrm{m}^{-1}$ (MAAS, 1993), at all studied salinity levels, except the lowest one $(0.8$ $\mathrm{dS} \mathrm{m} \mathrm{m}^{-1}$ ), reaching up to $5.45 \mathrm{dS} \mathrm{m}^{-1}$ for the salinity level of $4.0 \mathrm{dS} \mathrm{m}^{-1}$. Thus, at 60 DASSA, there was a higher salinity effect on the plants, which caused reduction in net photosynthesis and carboxylation efficiency, compared with the other periods (Tables 3 and 8), except for LCRSTC plants. The reduction in the photosynthetic rate of this genotype caused by salinity was similar among the periods.

Regarding the internal $\mathrm{CO}_{2}$ concentration, there was no significant effect of water salinity on the genotypes TSKC $\times$ CTSW - 033 and TSKC, which indicates that the low photosynthetic rate is not related to the availability of carbon dioxide in the substomatal chamber (Tables 4 and 6), but to the reduction in the activity of ribulose-1,5bisphosphate carboxylase/oxygenase (RuBisCO), also decreasing the consumption of $\mathrm{CO}_{2}$ and, consequently, compensating its inflow due to stomatal closure and salt stress, as explained by Silva et al. (2014).

The genotypes TSKC x CTSW - 028, LVK $\mathrm{x}$ LCR - 038 and TSKFL showed satisfactory levels of net photosynthesis in all evaluations, up to 2.4 $\mathrm{dS} \mathrm{m}{ }^{-1}$, since, according to the data of Medina et al. (2005) and Brito et al. (2012), photosynthesis values range from 4 to $10 \mu \mathrm{mol}\left(\mathrm{CO}_{2}\right) \mathrm{m}^{-2} \mathrm{~s}^{-1}$. It should be pointed out that the internal $\mathrm{CO}_{2}$ concentrations of these genotypes showed a similar behaviour as the $\mathrm{CO}_{2}$ assimilation rate (Tables 3 and 4), even under stomatal limitations up to this salinity level, indicating the stress adaptation capacity of the photosynthetic processes of these genotypes. This can be related to the tolerance mechanism of dilution of the solute, because some genotypes can increase their photosynthetic activity and, consequently, the production of organic compounds, favouring cell growth and salt dilution within the plant (FLOWERS; FLOWERS, 2005; TAIZ; ZEIGER, 2013). 
Table 4. Internal $\mathrm{CO}_{2}$ concentration $\left(C_{i}\right)\left(\mu \mathrm{mol}\left(\mathrm{CO}_{2}\right) \mathrm{mol}^{-1}\right)$ to 15,30 and 60 days after salt stress application (DASSA) on citrus genotypes under different levels of salt stress from irrigation water.

\begin{tabular}{|c|c|c|c|c|c|}
\hline \multicolumn{6}{|c|}{ Internal $\mathrm{CO}_{2}$ concentration $\left(C_{i}\right)$} \\
\hline \multirow{3}{*}{ Genotype } & \multicolumn{4}{|c|}{15 DASSA } & \\
\hline & \multicolumn{5}{|c|}{ Salt stress from irrigation water $\left(\mathrm{dS} \mathrm{m}^{-1}\right)$} \\
\hline & 0.8 & 1.6 & 2.4 & 3.2 & 4 \\
\hline LCRSTC & $264 \mathrm{~A}$ & $253 \mathrm{~A}$ & $268 \mathrm{~A}$ & $240 \mathrm{~A}$ & $215 \mathrm{~A}$ \\
\hline TSKC x CTSW -028 & $277 \mathrm{~A}$ & $273 \mathrm{~A}$ & $277 \mathrm{~A}$ & $286 \mathrm{~A}$ & $264 \mathrm{AB}$ \\
\hline TSKC x CTSW -033 & $246 \mathrm{~A}$ & $256 \mathrm{~A}$ & $253 \mathrm{~A}$ & $254 \mathrm{~A}$ & $254 \mathrm{~A}$ \\
\hline TSKC x CTSW -041 & $259 \mathrm{~A}$ & $270 \mathrm{~A}$ & $258 \mathrm{~A}$ & $247 \mathrm{~A}$ & $254 \mathrm{AB}$ \\
\hline LVK x LCR - 038 & $273 \mathrm{~A}$ & $253 \mathrm{~A}$ & $247 \mathrm{~A}$ & $301 \mathrm{~A}$ & $261 \mathrm{~A}$ \\
\hline TSKFL & $274 \mathrm{~A}$ & $243 \mathrm{AB}$ & $279 \mathrm{~A}$ & $263 \mathrm{~A}$ & $250 \mathrm{~A}$ \\
\hline TSKC & $252 \mathrm{~B}$ & $236 \mathrm{~A}$ & $262 \mathrm{~A}$ & $251 \mathrm{~A}$ & $247 \mathrm{AB}$ \\
\hline LRF & $252 \mathrm{~A}$ & $258 \mathrm{~A}$ & $242 \mathrm{~A}$ & $252 \mathrm{~A}$ & $253 \mathrm{AB}$ \\
\hline \multicolumn{6}{|c|}{30 DASSA } \\
\hline \multirow{2}{*}{ Genotype } & \multicolumn{5}{|c|}{ Salt stress from irrigation water $\left(\mathrm{dS} \mathrm{m}^{-1}\right)$} \\
\hline & 0.8 & 1.6 & 2.4 & 3.2 & 4 \\
\hline LCRSTC & $253 \mathrm{~A}$ & $241 \mathrm{~A}$ & $254 \mathrm{AB}$ & $251 \mathrm{~A}$ & $234 \mathrm{~A}$ \\
\hline TSKC x CTSW -028 & $266 \mathrm{~A}$ & $248 \mathrm{~A}$ & $262 \mathrm{~A}$ & 244 B & 248 B \\
\hline TSKC x CTSW -033 & $278 \mathrm{~A}$ & $261 \mathrm{~A}$ & $246 \mathrm{~A}$ & $261 \mathrm{~A}$ & $265 \mathrm{~A}$ \\
\hline TSKC x CTSW -041 & $234 \mathrm{~A}$ & $251 \mathrm{~A}$ & $253 \mathrm{~A}$ & $265 \mathrm{~A}$ & $267 \mathrm{~A}$ \\
\hline LVK x LCR - 038 & $225 \mathrm{~B}$ & $272 \mathrm{~A}$ & $251 \mathrm{~A}$ & $250 \mathrm{~B}$ & $280 \mathrm{~A}$ \\
\hline TSKFL & $259 \mathrm{~A}$ & $265 \mathrm{~A}$ & 238 B & $260 \mathrm{~A}$ & $280 \mathrm{~A}$ \\
\hline TSKC & $307 \mathrm{~A}$ & $252 \mathrm{~A}$ & $241 \mathrm{~A}$ & $270 \mathrm{~A}$ & $273 \mathrm{~A}$ \\
\hline \multirow[t]{2}{*}{ LRF } & $209 \mathrm{~B}$ & $235 \mathrm{~A}$ & $266 \mathrm{~A}$ & $226 \mathrm{~A}$ & $268 \mathrm{~A}$ \\
\hline & \multicolumn{5}{|c|}{60 DASSA } \\
\hline \multirow{2}{*}{ Genotype } & \multicolumn{5}{|c|}{ Salt stress from irrigation water $\left(\mathrm{dS} \mathrm{m}^{-1}\right)$} \\
\hline & 0.8 & 1.6 & 2.4 & 3.2 & 4 \\
\hline LCRSTC & $257 \mathrm{~A}$ & $258 \mathrm{~A}$ & $234 \mathrm{~B}$ & $232 \mathrm{~A}$ & $218 \mathrm{~A}$ \\
\hline TSKC x CTSW -028 & $256 \mathrm{~A}$ & $257 \mathrm{~A}$ & $254 \mathrm{~A}$ & $263 \mathrm{AB}$ & 292 A \\
\hline TSKC x CTSW -033 & $246 \mathrm{~A}$ & $252 \mathrm{~A}$ & $255 \mathrm{~A}$ & $281 \mathrm{~A}$ & $257 \mathrm{~A}$ \\
\hline TSKC x CTSW -041 & $239 \mathrm{~A}$ & $237 \mathrm{~A}$ & $252 \mathrm{~A}$ & $238 \mathrm{~A}$ & $227 \mathrm{~B}$ \\
\hline LVK x LCR - 038 & $259 \mathrm{~A}$ & $239 \mathrm{~A}$ & $246 \mathrm{~A}$ & $272 \mathrm{AB}$ & $275 \mathrm{~A}$ \\
\hline TSKFL & $245 \mathrm{~A}$ & $227 \mathrm{~B}$ & $249 \mathrm{AB}$ & $245 \mathrm{~A}$ & $272 \mathrm{~A}$ \\
\hline TSKC & $236 \mathrm{~B}$ & $259 \mathrm{~A}$ & $243 \mathrm{~A}$ & $240 \mathrm{~A}$ & $218 \mathrm{~B}$ \\
\hline LRF & $244 \mathrm{~A}$ & $263 \mathrm{~A}$ & $243 \mathrm{~A}$ & $252 \mathrm{~A}$ & 222 B \\
\hline
\end{tabular}

* LCRSTC: 'Santa Cruz Rangupur' lime (Citrus limonia Osbeck); TSKC: common 'Sunki' mandarin [C. sunki (Hayata) hort. ex Tanaka]; CTSW: 'Swingle' citrumelo [C. paradisi Macfad. x Poncirus trifoliata (L.) Raf.]; LVK: 'Volkamer' lemon $(C$. volkameriana V. Ten. \& Pasq.); LCR: 'Rangpur' lime; TSKFL: 'Florida Sunki' mandarin; LRF: 'Florida rough lemon (C. jambhiri Lush.). Means followed by different letters indicate the difference between rootstocks by Tukey test at 0.05 probability level.

Regarding transpiration, there were alterations due to the increase of irrigation water salinity in the genotypes TSKC x CTSW - 033, TSKC $\mathrm{x}$ CTSW - 041 and TSKC in the first 15 DASSA, with reductions of $48.8,34.9$ and $47.7 \%$, respectively, in the comparison between the highest $\left(4.0 \mathrm{dS} \mathrm{m}^{-1}\right)$ and lowest $\left(0.8 \mathrm{dS} \mathrm{m}^{-1}\right)$ salinity levels (Table 5). These results coincided with the stomatal restrictions (Table 6); this was expected, as the stomata are responsible for regulating gas exchange (TAIZ; ZEIGER, 2013).
The reduction in stomatal activity (Table 6) influenced the reduction of water loss through transpiration in the genotypes, and these results confirm their sensitivity, as observed for $\mathrm{CO}_{2}$ assimilation rate and $\mathrm{CO}_{2}$ concentration, because the stomatal activity of these genotypes was affected during the first days under stress, which extended up to 30 and 60 DASSA, with drastic restrictions even at the lowest salinity levels (Tables 3, 4 and 8), related to the accumulation of salts in the saturation extract (Figure 1). 
Table 5. Transpiration $(E)\left(\mathrm{mmol}\left(\mathrm{H}_{2} \mathrm{O}\right) \mathrm{m}^{-2} \mathrm{~s}^{-1}\right)$ to 15,30 and 60 days after salt stress application (DASSA) on citrus genotypes under different levels of salt stress from irrigation water.

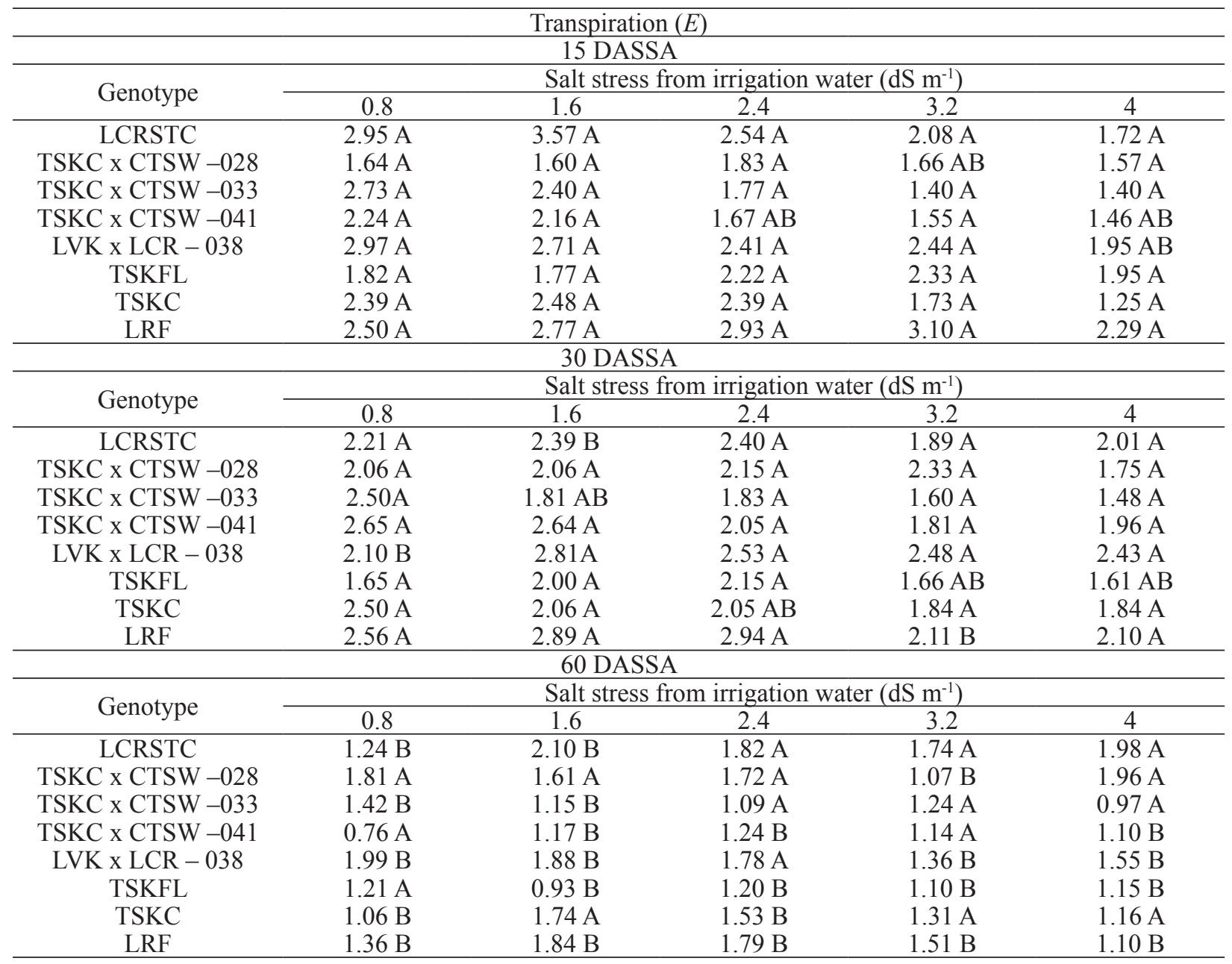

* LCRSTC: 'Santa Cruz Rangupur' lime (Citrus limonia Osbeck); TSKC: common 'Sunki' mandarin [C. sunki (Hayata) hort. ex Tanaka]; CTSW: 'Swingle' citrumelo [C. paradisi Macfad. x Poncirus trifoliata (L.) Raf.]; LVK: 'Volkamer' lemon (C. volkameriana V. Ten. \& Pasq.); LCR: 'Rangpur' lime; TSKFL: 'Florida Sunki' mandarin; LRF: 'Florida rough lemon (C. jambhiri Lush.). Means followed by different letters indicate the difference between rootstocks by Tukey test at 0.05 probability level.

We therefore conclude that salinity has different effects on citrus plants, depending on genotype and stress intensity and duration, corroborating the observations of Fernandes et al. (2011), Brito et al. (2014) and Silva et al. (2014).

After 30 DASSA, in the genotypes LCRSTC and LRF, stomatal and transpiration activities were affected by the increase in salinity, and this effect was less intense in LRF up to the water salinity level of $2.4 \mathrm{dS} \mathrm{m}^{-1}$ (Tables 5 and 6). On the other hand, in this evaluation period, the values of $g s$ and $E$ were maintained in the genotype LVK x LCR - 038 under water salinity, denoting of the capacity to maintain gas exchanges, including net photosynthesis, indicating salinity tolerance of this genotype. This behaviour was maintained at 60 DASSA, exhibiting similar values of $A, E$ and $g s$ up to the water salinity level of $2.4 \mathrm{dS} \mathrm{m}^{-1}$, which is higher than the threshold salinity for citrus in the irrigation water, $1.1 \mathrm{dS} \mathrm{m}^{-1}$ (AYERS; WESTCOT, 1999). 
Table 6. Stomatal conductance $(g s)\left(\mathrm{mol}\left(\mathrm{H}_{2} \mathrm{O}\right) \mathrm{m}^{-2} \mathrm{~s}^{-1}\right)$ to 15,30 and 60 days after salt stress application (DASSA) on citrus genotypes under different levels of salt stress from irrigation water.

\begin{tabular}{|c|c|c|c|c|c|}
\hline \multicolumn{6}{|c|}{ Stomatal conductance $(g s)$} \\
\hline \multicolumn{6}{|c|}{15 DASSA } \\
\hline \multirow{2}{*}{ Genotype } & \multicolumn{5}{|c|}{ Salt stress from irrigation water $\left(\mathrm{dS} \mathrm{m}^{-1}\right)$} \\
\hline & 0.8 & 1.6 & 2.4 & 3.2 & 4 \\
\hline LCRSTC & $0.17 \mathrm{~A}$ & $0.20 \mathrm{~A}$ & $0.12 \mathrm{~A}$ & $0.10 \mathrm{~A}$ & $0.08 \mathrm{~A}$ \\
\hline TSKC x CTSW -028 & $0.09 \mathrm{~A}$ & $0.08 \mathrm{~A}$ & $0.10 \mathrm{~A}$ & $0.10 \mathrm{AB}$ & $0.08 \mathrm{~A}$ \\
\hline TSKC x CTSW -033 & $0.15 \mathrm{~A}$ & $0.12 \mathrm{~A}$ & $0.08 \mathrm{~A}$ & $0.06 \mathrm{~A}$ & $0.06 \mathrm{~A}$ \\
\hline TSKC x CTSW -041 & $0.11 \mathrm{~A}$ & $0.11 \mathrm{~A}$ & $0.08 \mathrm{~A}$ & $0.07 \mathrm{~A}$ & $0.07 \mathrm{AB}$ \\
\hline LVK x LCR -038 & $0.19 \mathrm{~A}$ & $0.17 \mathrm{~A}$ & $0.16 \mathrm{~A}$ & $0.17 \mathrm{~A}$ & $0.12 \mathrm{~A}$ \\
\hline TSKFL & $0.09 \mathrm{~A}$ & $0.08 \mathrm{~A}$ & $0.12 \mathrm{~A}$ & $0.12 \mathrm{~A}$ & $0.10 \mathrm{~A}$ \\
\hline TSKC & $0.10 \mathrm{~A}$ & $0.10 \mathrm{~A}$ & $0.11 \mathrm{~A}$ & $0.07 \mathrm{~A}$ & $0.05 \mathrm{~A}$ \\
\hline \multirow[t]{2}{*}{ LRF } & $0.14 \mathrm{~A}$ & $0.15 \mathrm{~A}$ & $0.16 \mathrm{~A}$ & $0.18 \mathrm{~A}$ & $0.12 \mathrm{~A}$ \\
\hline & \multicolumn{4}{|c|}{30 DASSA } & \\
\hline \multirow{2}{*}{ Genotype } & \multicolumn{5}{|c|}{ Salt stress from irrigation water $\left(\mathrm{dS} \mathrm{m}^{-1}\right)$} \\
\hline & 0.8 & 1.6 & 2.4 & 3.2 & 4 \\
\hline LCRSTC & $0.14 \mathrm{~A}$ & $0.13 \mathrm{~B}$ & $0.13 \mathrm{~A}$ & $0.10 \mathrm{~A}$ & $0.09 \mathrm{~A}$ \\
\hline TSKC x CTSW -028 & $0.10 \mathrm{~A}$ & $0.11 \mathrm{~A}$ & $0.12 \mathrm{~A}$ & $0.13 \mathrm{~A}$ & $0.08 \mathrm{~A}$ \\
\hline TSKC x CTSW -033 & $0.13 \mathrm{~A}$ & $0.08 \mathrm{AB}$ & $0.08 \mathrm{~A}$ & $0.08 \mathrm{~A}$ & $0.06 \mathrm{~A}$ \\
\hline TSKC x CTSW -041 & $0.13 \mathrm{~A}$ & $0.13 \mathrm{~A}$ & $0.11 \mathrm{~A}$ & $0.09 \mathrm{~A}$ & $0.11 \mathrm{~A}$ \\
\hline LVK x LCR - 038 & $0.12 \mathrm{~B}$ & $0.14 \mathrm{AB}$ & $0.13 \mathrm{AB}$ & $0.12 \mathrm{AB}$ & $0.13 \mathrm{~A}$ \\
\hline TSKFL & $0.06 \mathrm{~A}$ & $0.08 \mathrm{~A}$ & $0.09 \mathrm{AB}$ & $0.07 \mathrm{AB}$ & $0.07 \mathrm{~A}$ \\
\hline TSKC & $0.11 \mathrm{~A}$ & $0.08 \mathrm{~A}$ & $0.08 \mathrm{~A}$ & $0.07 \mathrm{~A}$ & $0.07 \mathrm{~A}$ \\
\hline \multirow[t]{2}{*}{ LRF } & $0.12 \mathrm{AB}$ & $0.14 \mathrm{~A}$ & $0.14 \mathrm{~A}$ & $0.08 \mathrm{~B}$ & $0.09 \mathrm{AB}$ \\
\hline & \multicolumn{5}{|c|}{60 DASSA } \\
\hline \multirow{2}{*}{ Genotype } & \multicolumn{5}{|c|}{ Salt stress from irrigation water $\left(\mathrm{dS} \mathrm{m}^{-1}\right)$} \\
\hline & 0.8 & 1.6 & 2.4 & 3.2 & 4 \\
\hline LCRSTC & $0.06 \mathrm{~B}$ & $0.12 \mathrm{~B}$ & $0.09 \mathrm{~A}$ & $0.10 \mathrm{~A}$ & $0.09 \mathrm{~A}$ \\
\hline TSKC x CTSW -028 & $0.10 \mathrm{~A}$ & $0.09 \mathrm{~A}$ & $0.09 \mathrm{~A}$ & $0.06 \mathrm{~B}$ & $0.11 \mathrm{~A}$ \\
\hline TSKC x CTSW -033 & $0.06 \mathrm{~B}$ & $0.06 \mathrm{~B}$ & $0.05 \mathrm{~A}$ & $0.05 \mathrm{~A}$ & $0.04 \mathrm{~A}$ \\
\hline TSKC x CTSW -041 & $0.03 \mathrm{~B}$ & $0.05 \mathrm{~B}$ & $0.06 \mathrm{~A}$ & $0.05 \mathrm{~A}$ & $0.05 \mathrm{~B}$ \\
\hline LVK x LCR - 038 & $0.13 \mathrm{~B}$ & $0.11 \mathrm{~B}$ & $0.10 \mathrm{~B}$ & $0.08 \mathrm{~B}$ & $0.09 \mathrm{~A}$ \\
\hline TSKFL & $0.06 \mathrm{~A}$ & $0.05 \mathrm{~A}$ & $0.06 \mathrm{~B}$ & $0.05 \mathrm{~B}$ & $0.05 \mathrm{~A}$ \\
\hline TSKC & $0.05 \mathrm{~B}$ & $0.07 \mathrm{~A}$ & $0.06 \mathrm{~A}$ & $0.05 \mathrm{~A}$ & $0.04 \mathrm{~A}$ \\
\hline LRF & $0.07 \mathrm{~B}$ & $0.10 \mathrm{~A}$ & $0.08 \mathrm{~B}$ & $0.08 \mathrm{~B}$ & $0.04 \mathrm{~B}$ \\
\hline
\end{tabular}

* LCRSTC: 'Santa Cruz Rangupur' lime (Citrus limonia Osbeck); TSKC: common 'Sunki' mandarin [C. sunki (Hayata) hort. ex Tanaka]; CTSW: 'Swingle' citrumelo [C. paradisi Macfad. x Poncirus trifoliata (L.) Raf.]; LVK: 'Volkamer' lemon (C. volkameriana V. Ten. \& Pasq.); LCR: 'Rangpur' lime; TSKFL: 'Florida Sunki' mandarin; LRF: 'Florida rough lemon (C. jambhiri Lush.). Means followed by different letters indicate the difference between rootstocks by Tukey test at 0.05 probability level.

There was an increment in intrinsic water use efficiency (Table 7) with salt concentration of the water for most genotypes and in all evaluation periods, with values between 1.5 and $4.0\left[\mu \mathrm{mol}\left(\mathrm{CO}_{2}\right)\right.$ $\left.\mathrm{m}^{-2} \mathrm{~s}^{-1}\right]\left[\mathrm{mmol}\left(\mathrm{H}_{2} \mathrm{O}\right) \mathrm{m}^{-2} \mathrm{~s}^{-1}\right]^{-1}$, considered as normal for $\mathrm{C}_{3}$ plants, but lower than those observed by Brito et al. (2012), studying combinations of citrus scion-rootstocks under water stress in a greenhouse.

In response to prolonged salt stress, the IWUE of the genotypes under salt stress at 60 DASSA showed highest reduction between the lowest and highest salinity levels in the genotype TSKC x CTSW 028 , in the order of $41.5 \%$ (Table 7 ). The genotypes
LCRSTC, TSKC x CTSW - 041 and LRF showed increments in IWUE values, particularly TSKC $\mathrm{x}$ CTSW-041, in which the increase was mainly related to the increment in net photosynthesis. Considering that this variable explains the interactions between water consumption and photosynthetic rates (TAIZ; ZAIGER, 2013), positive responses for this variable are important under saline conditions, because they reflect the expression of tolerance mechanisms such as reduced transpiration, minimising the inflow of water and salts without compromising on photosynthetic activity, thereby reducing the toxic effects of specific ions (FLOWERS; FLOWERS, 2005). 
Table 7. Instantaneous water use efficiency (IWUE) $\left[\mu \mathrm{mol}\left(\mathrm{CO}_{2}\right) \mathrm{m}^{-2} \mathrm{~s}^{-1}\right]\left[\mathrm{mmol}\left(\mathrm{H}_{2} \mathrm{O}\right) \mathrm{m}^{-2} \mathrm{~s}^{-1}\right]^{-1}$ to 15,30 and 60 days after salt stress application (DASSA) on citrus genotypes under different levels of salt stress from irrigation water.

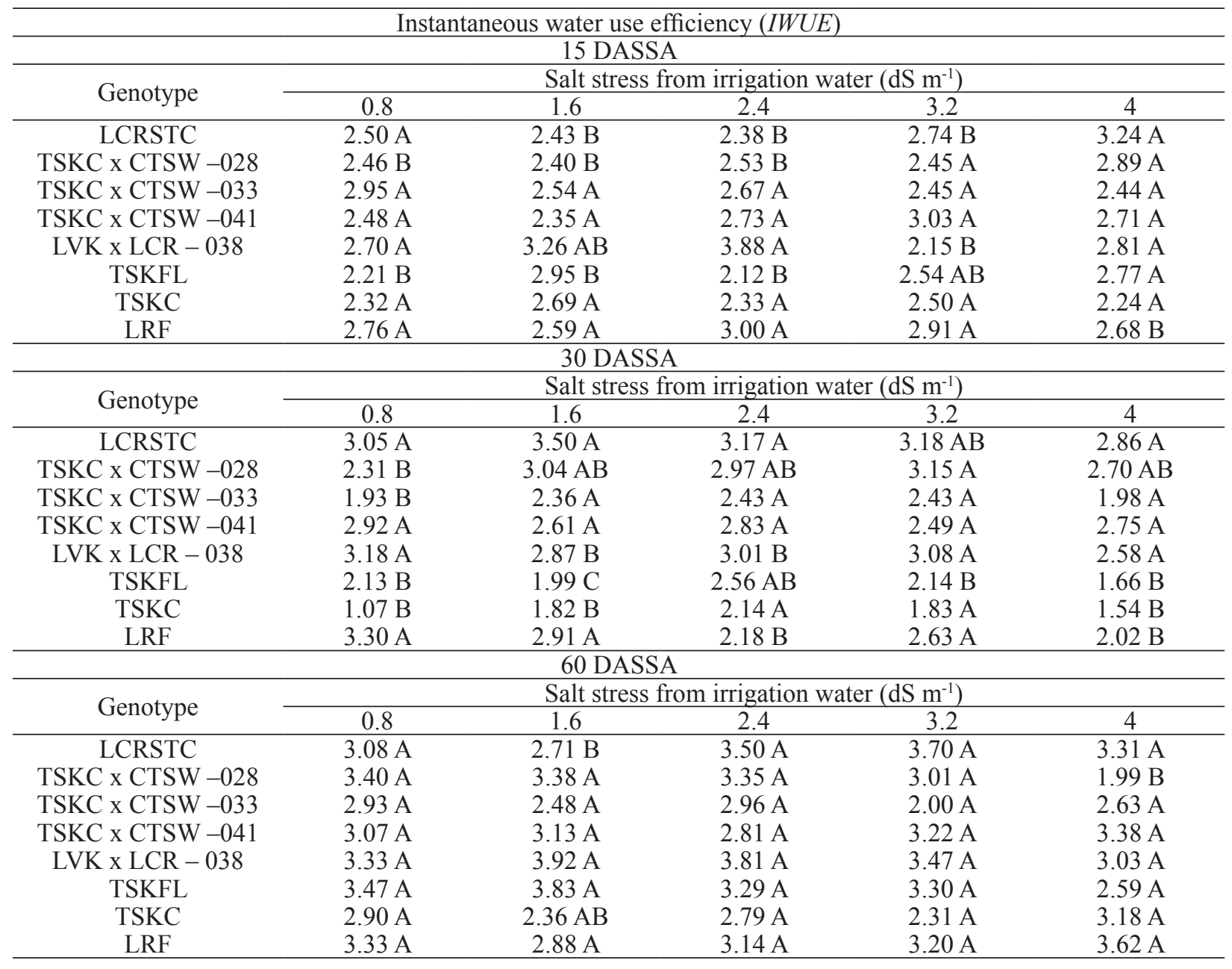

* LCRSTC: 'Santa Cruz Rangupur' lime (Citrus limonia Osbeck); TSKC: common 'Sunki' mandarin [C. sunki (Hayata) hort. ex Tanaka]; CTSW: 'Swingle' citrumelo [C. paradisi Macfad. x Poncirus trifoliata (L.) Raf.]; LVK: 'Volkamer' lemon (C. volkameriana V. Ten. \& Pasq.); LCR: 'Rangpur' lime; TSKFL: 'Florida Sunki' mandarin; LRF: 'Florida rough lemon (C. jambhiri Lush.). Means followed by different letters indicate the difference between rootstocks by Tukey test at 0.05 probability level.

In contrast, the negative effect on IWUE indicates sensitivity to salt stress, possibly due to the inability to minimise the osmotic effect of salinity, promoting water stress induced by salt stress (physiological drought) (RHOADES; LOVEDAY, 1990), which compromises the photosynthetic activity of the plant, as evidenced in the gas exchanges of the genotype TSKC x CTSW - 033 (Tables 3 and 6).
Regarding instantaneous carboxylation efficiency, there were alterations due to increased irrigation water salinity in the genotypes TSKC $\mathrm{x}$ CTSW - 033 and TSKC in the first 15 DASSA, with reductions of 60.6 and $47.7 \%$, respectively, comparing plants cultivated at the highest and lowest salinity levels. This variable was also altered by the prolongation of the stress from 15 to 30 and 60 DASSA, even at the lowest levels of water salinity (Table 8). 


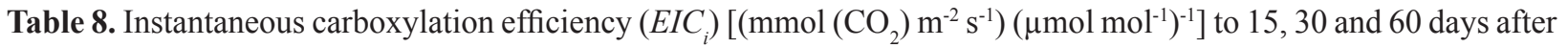
salt stress application (DASSA) on citrus genotypes under different levels of salt stress from irrigation water.

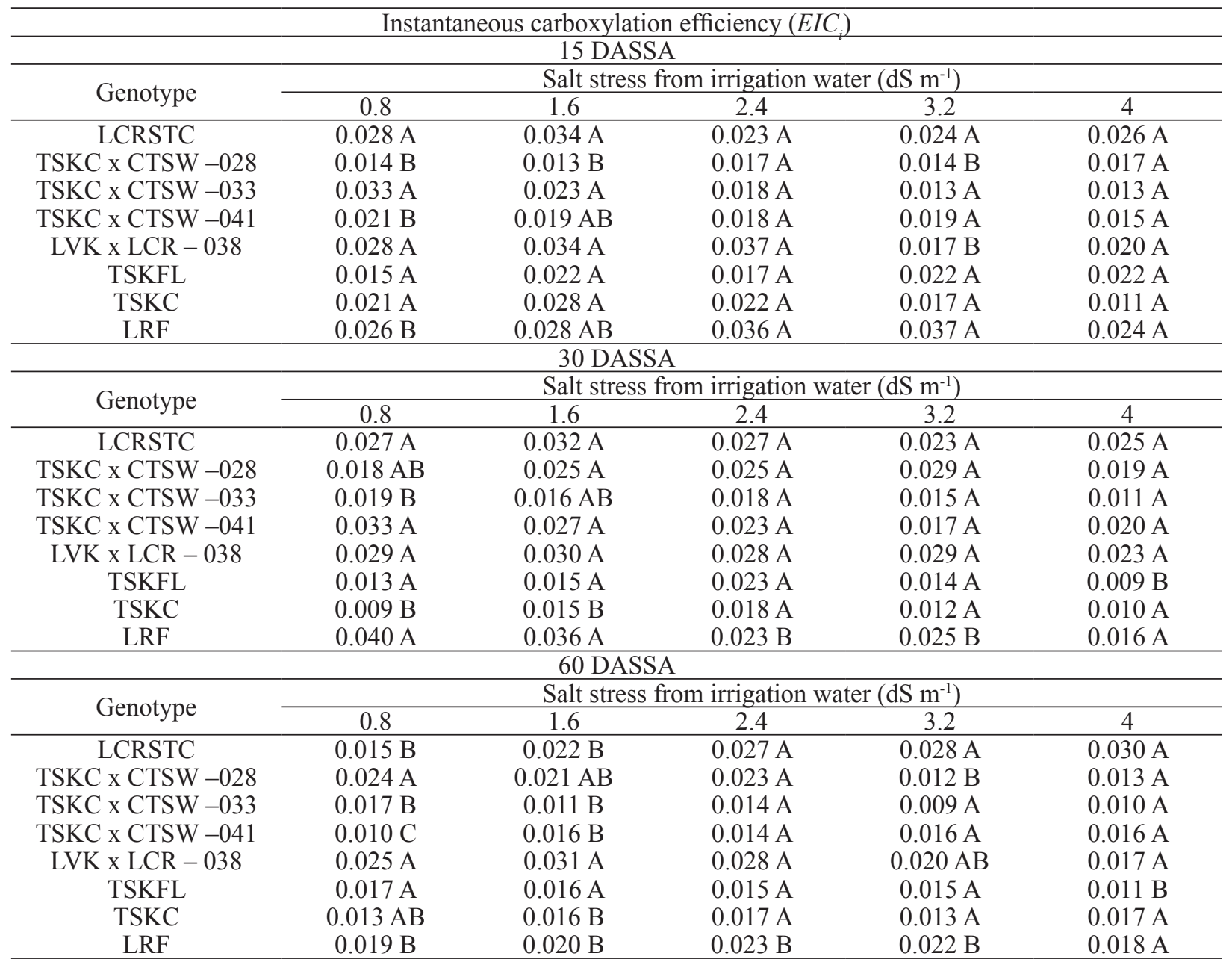

* LCRSTC: 'Santa Cruz Rangupur' lime (Citrus limonia Osbeck); TSKC: common 'Sunki' mandarin [C. sunki (Hayata) hort. ex Tanaka]; CTSW: 'Swingle' citrumelo [C. paradisi Macfad. x Poncirus trifoliata (L.) Raf.]; LVK: 'Volkamer' lemon (C. volkameriana V. Ten. \& Pasq.); LCR: 'Rangpur' lime; TSKFL: 'Florida Sunki' mandarin; LRF: 'Florida rough lemon (C. jambhiri Lush.). Means followed by different letters indicate the difference between rootstocks by Tukey test at 0.05 probability level.

Instantaneous carboxylation efficiency reflects the efficiency of $\mathrm{CO}_{2}$ consumption in the photosynthetic activity in relation to its availability in the substomatal chamber (TAIZ; ZEIGER, 2013). Given the low photosynthetic activities of these genotypes, this behaviour is mainly related to the reduction in $\mathrm{RuBisCO}$ activity because, besides stomatal restrictions, salinity also caused small restrictions in the internal $\mathrm{CO}_{2}$ concentrations of these genotypes.
In the genotypes LCRSTC, TSKC x CTSW 041 and LRF, until the first 30 DASSA, the EIC was satisfactory, which has also been observed by Brito et al. (2012), who conducted studies under similar climatic conditions (Table 8).

The opposite was observed in the genotypes LVK x LCR - 038 and TSKFL, which did not suffer from salt stress up to salinity levels of 2.4 and $3.2 \mathrm{dS} \mathrm{m}^{-1}$, respectively, even at 60 days of stress, indicating the tolerance of these genotypes to increased water salinity. 


\section{Conclusions}

Water salinity reduces the gas exchanges of citrus genotypes, which is more evident at 15 days after the beginning of the stress, i.e., at 75 days after sowing.

The genotypes 'Santa Cruz Rangpur' lime, LVK x LCR - 038, 'Florida Sunki' mandarin and 'Florida' rough lemon have higher physiological potential, even under salt stress conditions.

The genotypes 'Santa Cruz Rangpur' lime, TSKC x CTSW - 041, LVK x LCR - 038 and 'Florida' rough lemon exhibit a satisfactory physiological behaviour during the first 30 days of exposure to the stress (DASSA), showing moderate tolerance to salt stress.

The genotypes TSKC x CTSW - 033 and common 'Sunki' mandarin are the most sensitive to salinity.

Cultivation of plants in $115 \mathrm{~mL}$ tubes under saline water irrigation should only be conducted up to 90 days after sowing, as prolonged cultivation under such conditions reduces the physiological potential of the plants.

\section{Acknowledgements}

To CNPq, Brazilian National Council of Scientific and Technological Development, and Embrapa Cassava \& Fruits.

\section{References}

AYERS, R. S.; WESTCOT, D. W. A qualidade da água na agricultura. Campina Grande: UFPB, 1999. 184 p. (Estudos da FAO Irrigação e Drenagem, 29).

BRAZ, V. B.; RAMOS, M. M.; ANDRADE JÚNIOR, A. S. de; SOUSA, C. A. F. de; MANTOVANI, E. C. Níveis e frequências de irrigação na limeira Tahiti no Estado do Piauí. Revista Ceres, Viçosa, MG, v. 56, n. 5, p. 611-619, 2009.
BRITO, M. E. B.; FERNANDES, P. D.; GHEYI, H. R.; MELO, A. S.; SOARES FILHO, W. dos S.; SANTOS, R. T. Sensibilidade à salinidade de híbridos trifoliados e outros porta-enxertos de citros. Revista Caatinga, Mossoró, v. 27, n. 1, p. 17-27, 2014.

BRITO, M. E. B.; SÁ, F. V. S.; SOARES FILHO, W. S., SILVA, L. A.; FERNANDES, P. D. Gas exchange and fluorescence of citrus rootstocks varieties under saline stress. Revista Brasileira de Fruticultura, Jaboticabal, v. 38, n. 2: e-951, p 1-8, 2016.

BRITO, M. E. B.; SOARES, L. A. dos A.; FERNANDES, P. D.; LIMA, G. S.; SÁ, F. V. da S.; MELO, A. S. Comportamento fisiológico de combinações copa/portaenxerto de citros sob estresse hídrico. Revista Brasileira de Ciências Agrárias, Recife, v. 7, p. 857-865, 2012. Suplemento.

CARVALHO, S. A.; GRAF, C. C. D.; VIOLANTE, A. R. Produção de material básico e propagação. In: MATTOS JUNIOR, D.; NEGRI, J. R.; PIO, R. M.; POMPEU JUNIOR, J. (Ed). Citros. Campinas: Instituto Agronômico e Fundag, 2005. p. 483-680.

DIAS, N. da S.; BLANCO, F. F. Efeitos dos sais no solo e na planta. In: GHEYI, H. R.; DIAS, N. S.; LACERDA, C. F. de. (Ed.). Manejo da salinidade na agricultura: estudos básicos e aplicados. Fortaleza: INCTSal, 2010. p. 129-141

DIAS, T. J.; CAVALCANTE, L. F.; NUNES, J. C.; FREIRE, J. L. O.; NASCIMENTO, J. A. M. Qualidade física e produção do maracujá amarelo em solo com biofertilizante irrigado com águas salinas. Semina: Ciências Agrárias, Londrina, v. 33, p. 2905-2918, 2012. Suplemento 1.

EMPRESA BRASILEIRA DE PESQUISA AGROPECUÁRIA - EMBRAPA. Manual de análises químicas de solos, plantas e fertilizantes. 2. ed. rev. e ampl. Brasília: Embrapa Informação Tecnológica, 2009. $628 \mathrm{p}$.

FERNANDES, P. D.; BRITO, M. E. B.; GHEYI, H. R.; SOARES FILHO, W. dos S.; MELO, A. S.; CARNEIRO, P. T. Crescimento de híbridos e variedades porta-enxerto de citros sob salinidade. Acta Scientiarum. Agronomy, Maringá, v. 33, n. 2, p. 259-267, 2011.

FERREIRA, D. F. Sisvar: a computer statistical analysis system. Ciência Agrotecnologia, Lavras, v. 35, n. 6, p. 1039-1042, 2011.

FLOWERS, T. J.; FLOWERS, S. A. Why does salinity pose such a difficult problem for plant breeders? Agricultural Water Management, New York, v. 78, n. 1, p. 15-24, 2005. 
FOOD AND AGRICULTURE ORGANIZATION OF THE UNITED NATIONS - FAO. Statistical yearbook. Rome: FAO-Editora, 2014. Available at: <http://www. fao.org/docrep/015/i2490e/i2490e00>. Accessed at: 18 abr. 2016.

HUSSAIN, S.; MORILLON, R.; ANJUM, M. A.; OLLITRAUlT, P.; COSTANTINO, G.; LURO, F. Genetic diversity revealed by physiological behavior of citrus genotypes subjected to salt stress. Acta Physiology Plantarum, Varsovia, v. 37, n. 1, p. 1740-1750, 2015.

INSTITUTO BRASILEIRO DE GEOGRAFIA E ESTATÍSTICA - IBGE. Levantamento sistemático da produção agrícola. Rio de Janeiro: Fundação IBGE, mar. 2016. Disponível em: <http://www.sidra.ibge.gov. $\mathrm{br} / \mathrm{bda} /$ default.asp? $\mathrm{t}=5 \& \mathrm{z}=\mathrm{t} \& \mathrm{o}=1 \& \mathrm{u} 1=1 \& \mathrm{u} 2=1 \& \mathrm{u} 3=$ $1 \& u 4=1 \& u 5=1 \& u 6=1 \& u 7=1 \& u 8=1 \& u 9=1 \& u 10=1 \&$ u $11=1 \& u 12=3 \& u 13=1 \& u 14=26674 \& u 15=1 \& u 16=1$ $\& u 17=1>$. Acesso em: 18 abr. 2016.

LEVY, Y.; SYVERTSEN, J. Irrigation water quality and salinity. Effects in citrus trees. Horticultural Reviews, Nova York, v. 30, n. 1, p. 37-82, 2004.

MAAS, E. V. Salinity and citriculture. Tree Physiology, Victoria, v. 12, n. 2, p. 195-216, 1993.

MACHADO, D. F. S. P.; MACHADO, E. C.; MACHADO, R. S.; RIBEIRO, R. V. Efeito da baixa temperatura noturna e do porta-enxerto na variação diurna das trocas gasosas e na atividade fotoquímica de laranjeira Valência. Revista Brasileira de Fruticultura, Jaboticabal, v. 32, n. 2, p. 351-359, 2010.

MACHADO, E. C.; SCHMIDT, P. T.; MEDINA, C. L.; RIBEIRO, R. V. Respostas da fotossíntese a fatores ambientais em três espécies de citros. Pesquisa Agropecuária Brasileira, Brasília, v. 40, n. 12, p. 11611170, 2005.

MEDEIROS, J. F.; LISBOA, R. de A.; OLIVEIRA, M.; SILVA JÚNIOR, M. J.; ALVES, L. P. Caracterização das águas subterrâneas usadas para irrigação na área produtora de melãona Chapada do Apodi. Revista Brasileira de Engenharia Agrícola e Ambiental, Campina Grande, v. 7, n. 3, p. 469-472, 2003.
MEDINA, C. L.; RENA, A. B.; SIQUEIRA, D. L.; MACHADO, E. C. Fisiologia dos citros. In: MATTOS JUNIOR, D.; NEGRI, J. R.; PIO, R. M.; POMPEU JUNIOR, J. (Ed.). Citros. Campinas: Instituto Agronômico e Fundag, 2005. p. 149-195.

QUAGGIO, J. A.; MATTOS JUNIOR, D.; CANTARELLA, H. Manejo da fertilidade do solo na citricultura. In: MATTOS JUNIOR, D.; NEGRI, J. R.; PIO, R. M.; POMPEU JUNIOR, J. (Ed.). Citros. Campinas: Instituto Agronômico e Fundag, 2005. p. 483680.

REBEQUI, A. M.; CAVALCANTE, L. F.; NUNES, J. C.; DINIZ, A. A.; BREHM, M. A. da S.; BECKMANNCAVALCANTE, M. Z. Produção de mudas de limão cravo em substrato com biofertilizante bovino irrigado com águas salinas. Revista de Ciências Agrárias, Lisboa, v. 32, n. 2, p. 219-228, 2009.

RHOADES, J. D.; LOVEDAY, J. Salinity in irrigated agriculture. In: STEWART, D. R.; NIELSEN, D. R. (Ed.). Irrigation of agricultural crops. Madison: ASA, CSSA, SSSA, 1990. p. 1089-1142. (Agronomy, 30).

SILVA, L.A.;BRITO, M.E.B.; SÁ, F. V. da S.; MOREIRA, R. C. L.; SOARES FILHO, W. dos S.; FERNANDES, P. D. Mecanismos fisiológicos em híbridos de citros sob estresse salino em cultivo hidropônico. Revista Brasileira Engenharia Agrícola e Ambiental, Campina Grande, v. 18, p. S1-S7, 2014. Suplemento.

SYVERTSEN, J. P.; GARCIA-SANCHEZ, F. Multiple abiotic stresses occurring with salinity stress in citrus. Environmental and Experimental Botany, Oxford, v. 103, n. 1, p. 128-137, 2014.

TAIZ, L.; ZEIGER, E. Fisiologia vegetal. 5. ed. Porto Alegre: Artmed, 2013. 918 p.

TESTER, M.; DAVENPORT, R. Na ${ }^{+}$tolerance and $\mathrm{Na}^{+}$ transport in higher plants. Annals of Botany, Oxford, v. 91, n. 5, p. 503-527, 2003. 